Nevada

Environmental

Restoration

Project

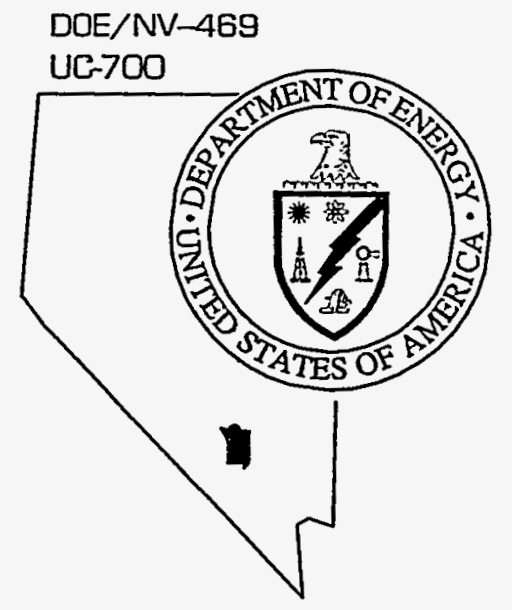

\title{
Closure Report for CAU No. 430: Buried Depleted Uranium Artillery Round No. 1, Tonopah Test Range
}

Colpron

Revision: 0

February 1997

Environmental Restoration

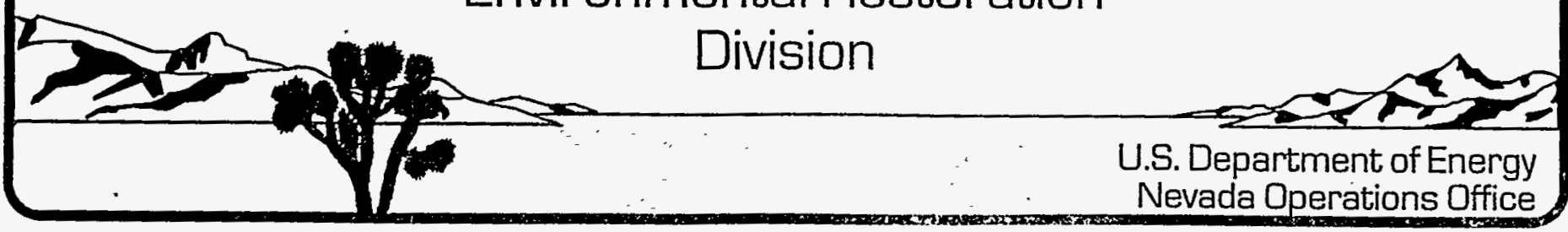


This report has been reproduced from the best available copy. Available in paper copy and microfiche.

Number of pages in this report: 25

DOE and DOE contractors can obtain copies of this report from: Office of Scientific and Technical Information, P.O. Box 62, Oak Ridge, TN 37831. (615) 576-8401.

This report is publicly available from the Department of Commerce, National Technical Information Service, 5285 Port Royal Road, Springfield, VA 22161. (703) 487-4650. 


\section{CLOSURE REPORT FOR CAU NO. 430: BURIED DEPLETED URANIUM ARTILLERY ROUND NO. 1, TONOPAH TEST RANGE}

DOE Nevada Operations Office

Las Vegas, Nevada

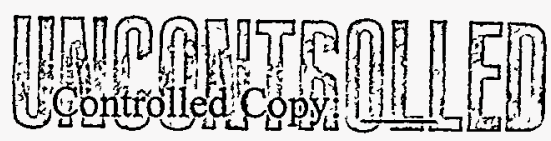

Revision: 0

February 1997

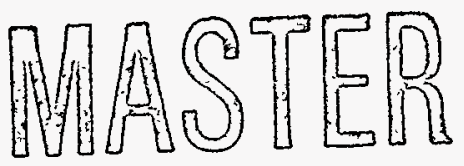




\section{DISCLAIMER}

Portions of this document may be illegible electronic image products. Images are produced from the best available original document. 


\section{CLOSURE REPORT FOR CAU NO. 430: \\ BURIED DEPLETED URANIUM ARTILLERY ROUND NO. 1, TONOPAH TEST RANGE}

Approved by: Sabine T. Curtis

Date: $2 / 25 / 97$

for Stephen Mellington, Project Manager

Nevada Environmental Restoration Project

Approved by: $\frac{\text { Saret }}{\text { Janet Appenzetier-Wing, Project Manage }}$

Date: $2 / 25 / 97$

Industrial Sites Subproject 


\section{Table of Contents}

List of Figures

List of Acronyms and Abbreviations iii

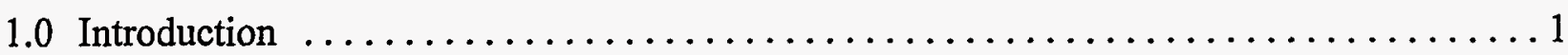

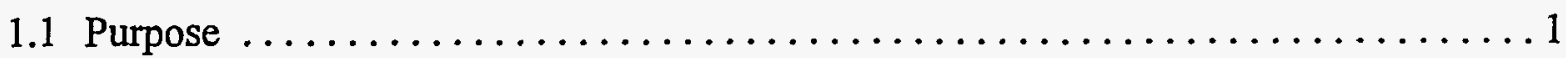

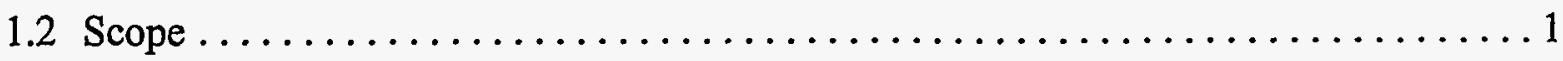

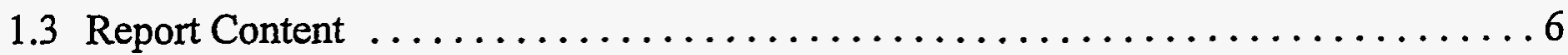

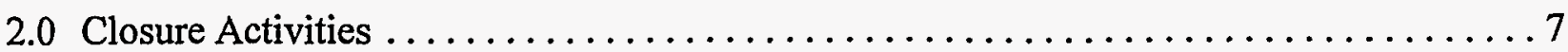

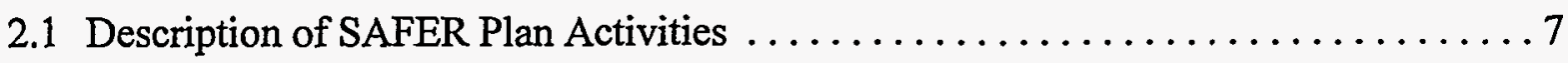

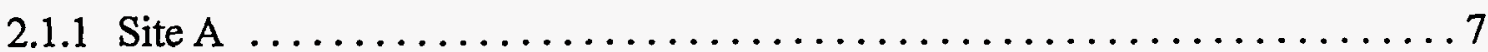

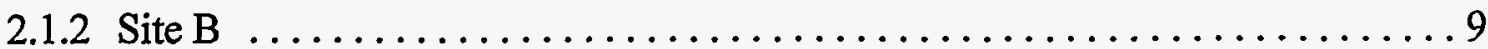

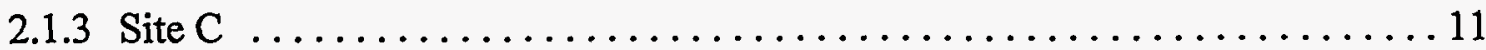

2.2 Deviations from the SAFER Plan as Approved $\ldots \ldots \ldots \ldots \ldots \ldots \ldots \ldots \ldots \ldots$

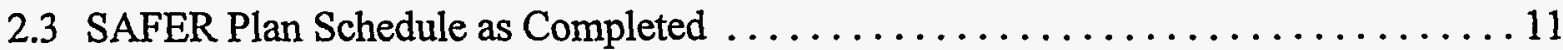

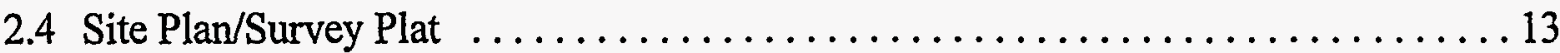

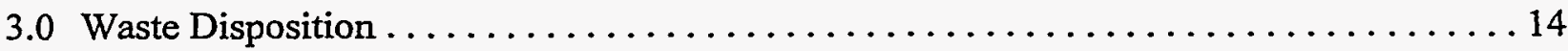

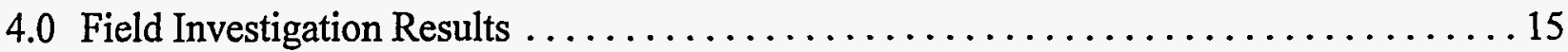

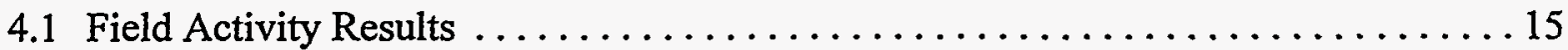

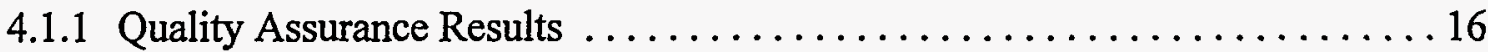

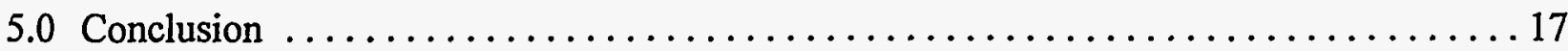

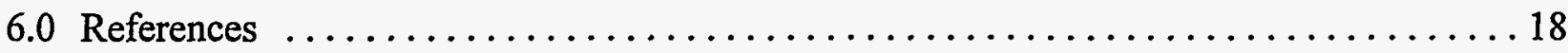




\section{List of Figures}

Number

Title

Page

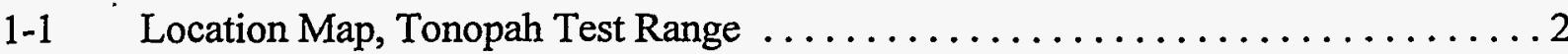

1-2 Site Layout, Tonopah Test Range.$\ldots \ldots \ldots \ldots \ldots \ldots \ldots \ldots \ldots \ldots$

1-3 Site Location Map, Buried DU Artillery Round No. 1,

Sites A-1, A-2, B, and C, Tonopah Test Range, Nye County, Nevada ......... 4

2-1 Buried DU Artillery Round No. 1, Sites A-1 and A-2, Site A-1 is in the

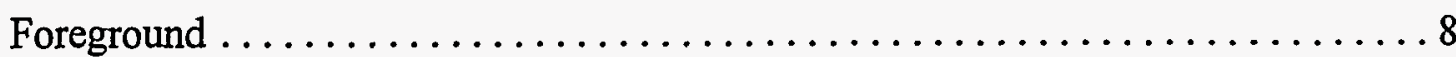

2-2 Buried DU Artillery Round No. 1, Site A-1,

Geophone sensor is on right side of excavation $\ldots \ldots \ldots \ldots \ldots \ldots \ldots \ldots \ldots$

2-3 Buried'DU Artillery Round No. 1, Site A-2,

Excavated projectile within excavation prior to detonation $\ldots \ldots \ldots \ldots \ldots \ldots 10$

2-4 Buried DU Artillery Round No. 1, Detonation

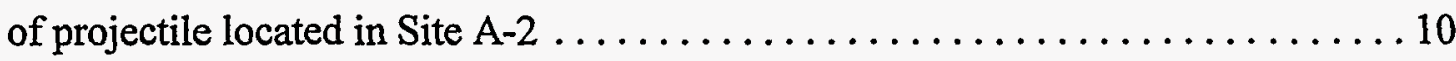

2-5 Buried DU Artillery Round No. 1, Site B,

Surveying edge of excavation with a Tesoro Lobo metal detector $\ldots \ldots \ldots \ldots 12$

2-6 Buried DU Artillery Round No. 1, Site C $\ldots \ldots \ldots \ldots \ldots \ldots \ldots \ldots \ldots \ldots \ldots \ldots$ 


\section{List of Acronyms and Abbreviations}

CAS Corrective Action Site

CAU Corrective Action Unit

DOE U.S. Department of Energy

DOE/AL DOE Albuquerque Operations Office

DOE/NV DOE Nevada Operations Office

DQO Data Quality Objective(s)

DU Depleted uranium

EOD Explosive Ordnance Disposal

$\mathrm{ft} \quad$ Foot (feet)

$\mathrm{ft}^{3} \quad$ Cubic foot (feet)

GPS Global Positioning Survey

HE High explosives

in. Inch(es)

IT IT Corporation

JTA Joint Test Assembly

km Kilometer(s)

lb Pound(s)

m $\quad$ Meter(s)

$\mathrm{m}^{3} \quad$ Cubic meter(s)

mi Mile(s)

NDEP Nevada Division of Environmental Protection

SAFER Streamlined Approach for Environmental Restoration

SVOC Semivolatile organic compound

TTR Tonopah Test Range

USAF United States Air Force

UXO Unexploded ordnance

$\mathrm{yd}^{3} \quad$ Cubic yard(s) 


\subsection{Introduction}

Corrective Action Unit (CAU) 430 consists of one Corrective Action Site (CAS), the Buried Depleted Uranium (DU) Artillery Round No. 1 (CAS No. TA-55-003-09-60), and is located on the U.S. Department of Energy (DOE) Tonopah Test Range (TTR) in south-central Nevada (Figures 1-1 and 1-2).

\subsection{Purpose}

This Closure Report presents the information obtained from investigative actions performed to justify the decision for clean closure of CAU 430 through "No Further Action." The investigative actions were performed per the Streamlined Approach for Environmental Restoration Plan, CAU No. 430: Buried Depleted Uranium Artillery Round No. 1, Tonopah Test Range (DOE/NV, 1996a) (hereafter referred to as the SAFER Plan).

The Buried DU Artillery Round No. 1 is located approximately 1.1 kilometers $(\mathrm{km})$ (0.7 mile [mi]) south of Avenue 13 in the test area south of Area 9 (Figure 1-2). The site was thought to consist of a potentially unexploded W-79 Joint Test Assembly (JTA) test artillery projectile with high explosives (HE) and DU. The DU was substituted for Special Nuclear Material to prevent a nuclear explosion and yet retain the physical characteristics of uranium for ballistic and other mechanical tests. The projectile was reportedly buried in one pit, approximately 5 to 10 feet (ft) deep (Smith, 1993; Smith, 1996; Quas, 1996). The exact location of the burial pit is unknown; however, three disturbed areas (Sites A, B, and C) were identified through geophysical surveys, site visits, and employee interviews as possible locations of the test projectile (Figure 1-3). Results of the investigation are summarized within this Closure Report. Additional information about the site and investigation activities may be found in the SAFER Plan (DOE/NV, 1996a).

\subsection{Scope}

The objectives of the SAFER Plan (DOE/NV, 1996a) activities were to prepare the site for closure through locating and identifying the projectile (Buried DU Artillery Round No. 1), destroying the projectile and any remaining components, collecting soil samples to detect residual contamination resulting from projectile destruction, and finally, remediating residual contamination. 


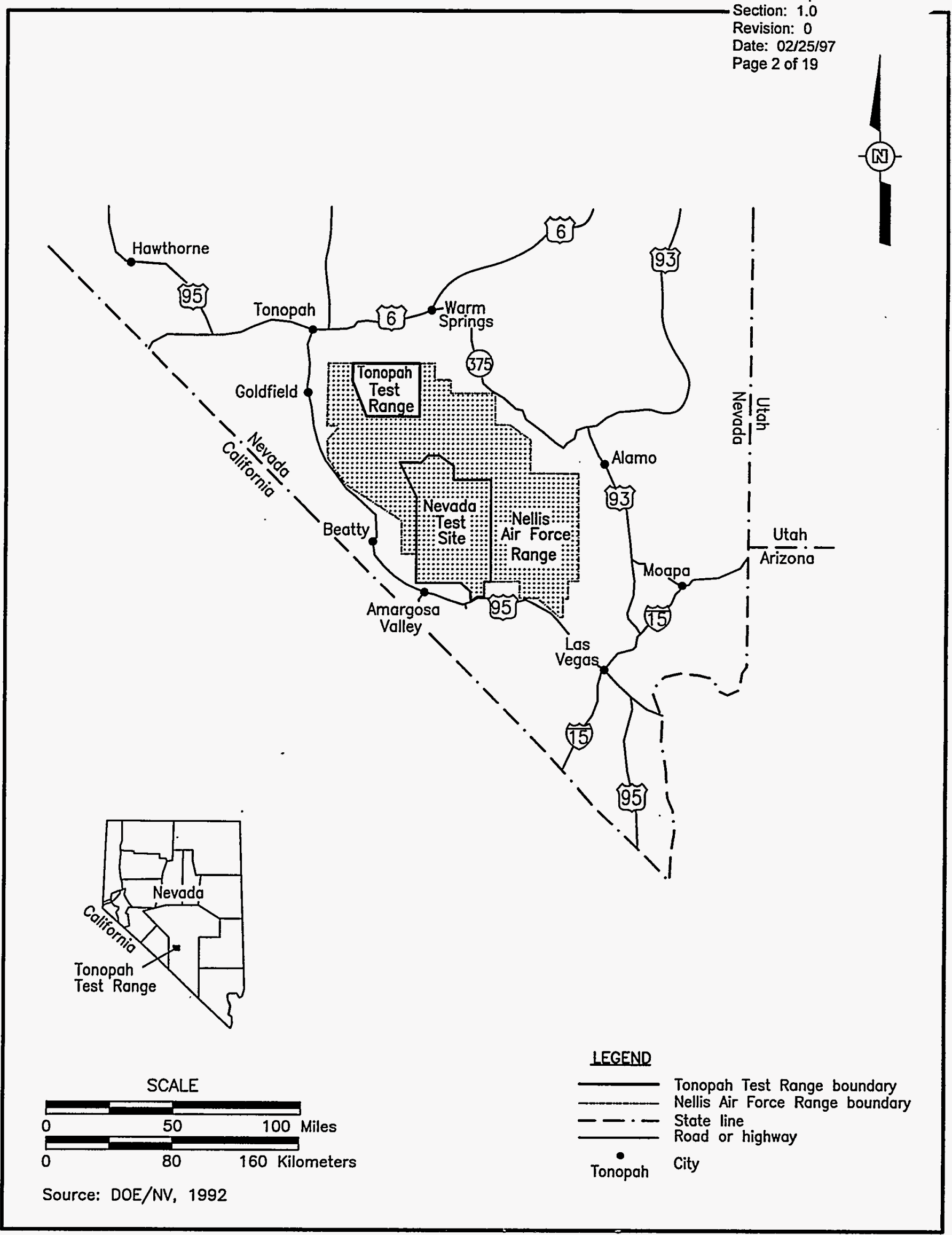




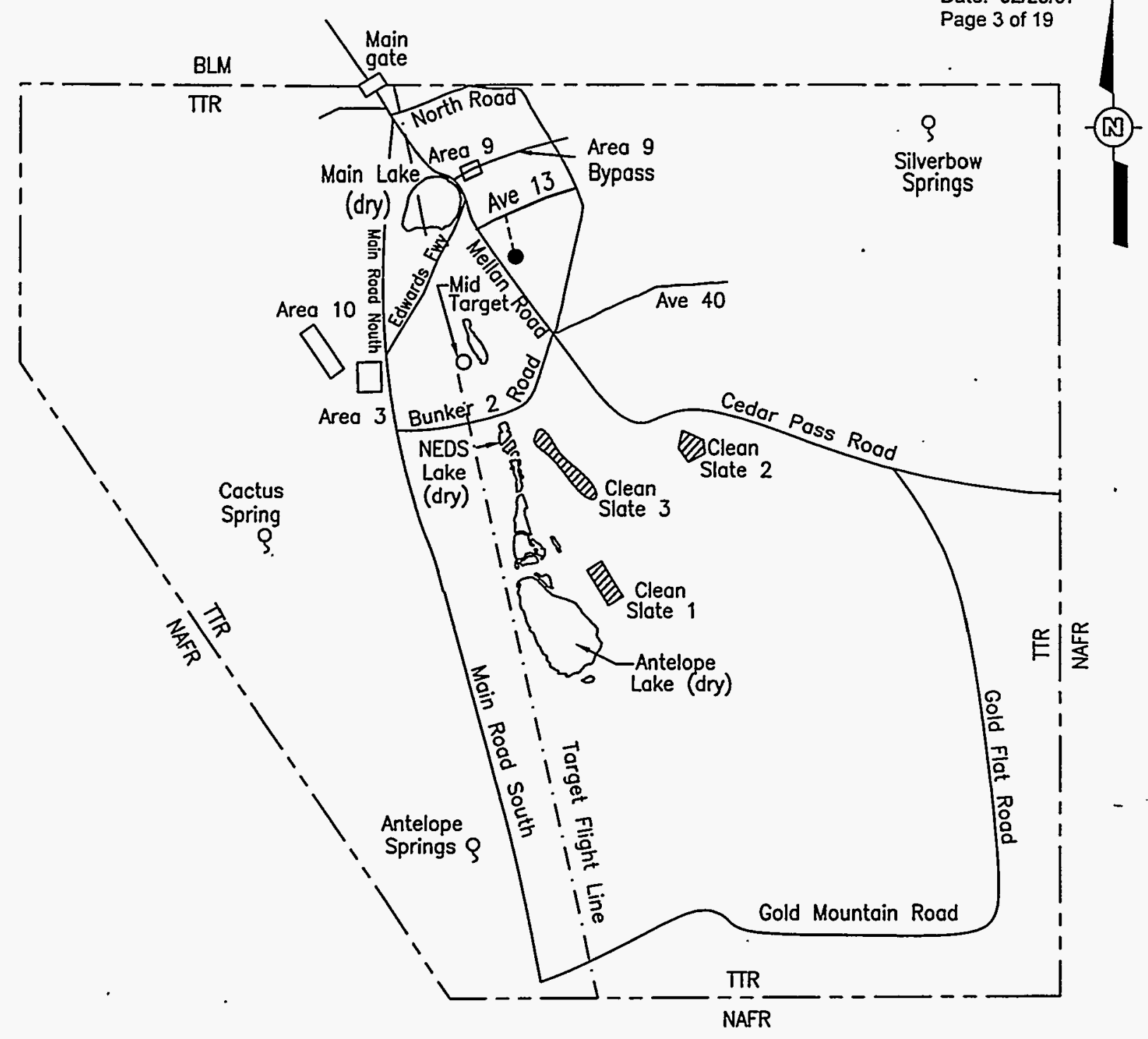

SCALE

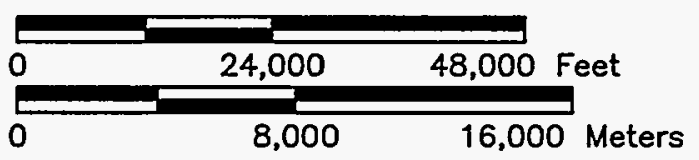

Source: Adapted from DOE/AL, 1992
LEGEND

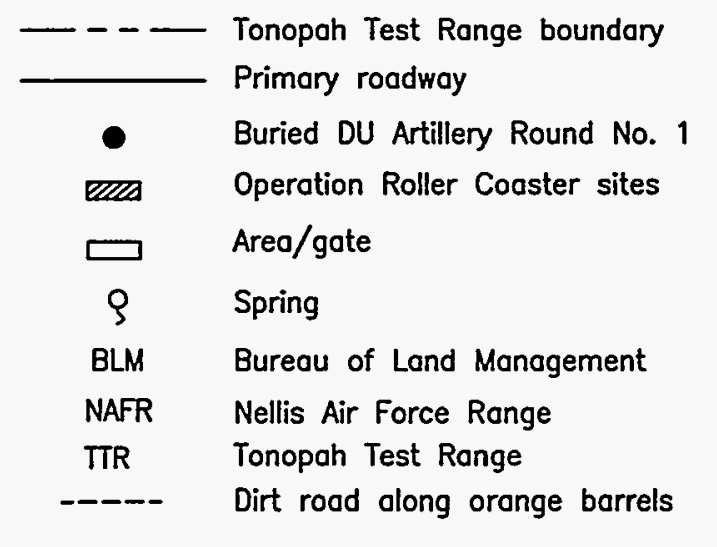




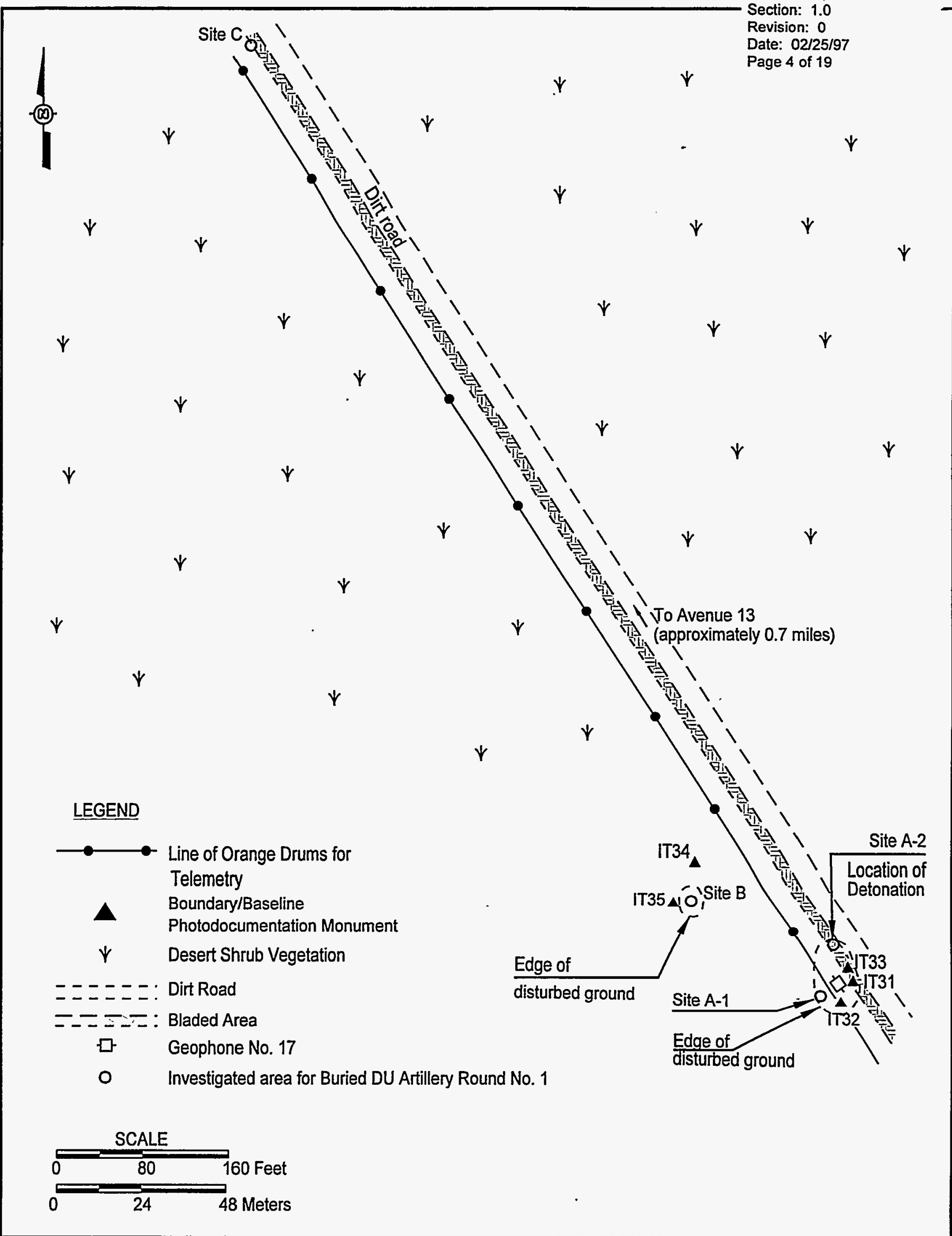

Figure 1-3

Site Location Map, Buried DU Artillery Round No.1, Sites A-1, A-2, B, and C Tonopah Test Range, Nye County, Nevada 
A conceptual model was designed to assist in developing Data Quality Objectives (DQOs) for the SAFER Plan. Both the model and DQOs are presented in Appendix A of the SAFER Plan (DOE/NV, 1996a). The following assumptions regarding the projectile were considered.

- The projectile is located in one of the three suspected locations.

- Some components of the projectile contain depleted uranium (U-238), chromium, mercury, and lead.

- The disposition of the projectile is unknown (i.e., whether the projectile is intact).

- The projectile is assumed to contain unexploded $\mathrm{HE}$ and must be destroyed in-place before it is safe to remove.

The DQOs were formulated based on locating and destroying the Buried DU Artillery Round No. 1 projectile. The primary contamination source of concern identified from the model for field activities was source fragments or particles of DU from the destruction of the projectile. It was felt that these fragments or particles would be located as hot spots in or around the area of detonation through field radiological screening. This formation would be used to determine if the Buried DU Artillery Round No. 1 had been located and destroyed. Radiological screening results would also be used during initial excavation to determine if the projectile was intact. Elevated radiological readings would suggest that the projectile was indeed located and was not intact. If the projectile was located, these were the two most likely events that would occur.

In October 1996, field investigation activities were conducted at Sites A, B, and C by IT Corporation (IT) and United States Air Force (USAF) Explosive Ordnance Disposal (EOD) personnel to locate and assess the condition of the projectile (see Section 2.0, Closure Activities). A different projectile (inert, concrete-filled) was located in place of the mock-up of the W-79 containing DU. Because the mock W-79 projectile was not located during the SAFER Plan (DOE/NV, 1996a) activities, the DQOs were not applied; samples were not collected; and no contamination was present to remediate. The assumption that the mock W-79 projectile is located in one of three suspected areas is incorrect. All other assumptions regarding the projectile still remain as assumptions. Investigations on the location and status of the mock W-79 JTA associated with the Buried DU Artillery Round No. 1 will be placed under a new CAU. This site will also be assigned a new CAS name and number, and new efforts to locate the actual location of the mock W-79 associated with the failed test in 1987 (SNL, 1988). 


\subsection{Report Content}

This report contains the following five sections. Section 1.0 introduces the CAU and scope of work. Section 2.0 of this report presents the closure activities performed as part of this investigation. Waste disposition is discussed in Section 3.0. Closure investigation results are presented in Section 4.0, and references are presented in Section 5.0.

Complete field documentation, including Field Activity Daily Logs and Daily Summaries, is retained in project files and will be supplied upon written request. Descriptions of the site history, potential waste to be generated, and site inventories are contained in the SAFER Plan (DOE/NV, 1996a). 


\subsection{Closure Activities}

Field investigation activities conducted at Sites A, B, and C at the DU Round No. 1 site involved obtaining a background radiological reading for the area, performing an initial magnetic survey of the sites, and excavating the sites until the magnetic anomalies were located or magnetic readings no longer existed. One detonation was conducted within Site A; no soil samples were collected during this investigation. Additional information is provided in Sections 2.1 through 2.4 of this report.

\subsection{Description of SAFER Plan Activities}

Prior to excavation activities at the three sites, a Forester Fere ${ }^{\otimes}$ ordnance detector was used to perform a magnetic survey to determine the location within each site with the strongest anomaly reading. A background radiological reading was also obtained for the three sites using an Electra ${ }^{\circledR}$ alpha/beta meter. Once the area with the strongest reading was established, soil was excavated in one-foot lifts using a backhoe. Prior to the excavation of each lift, the soil was surveyed for magnetic anomalies using a Schonstedt GA-52 Heliflux ${ }^{\otimes}$ magnetic locator and for radiological contamination using an Electra ${ }^{\circledast}$ alpha/beta meter.

\subsubsection{Site A}

Site $\mathrm{A}$ is the southernmost area of concern at the CAS. It consisted of a disturbed area approximately 30 feet (ft) in diameter. Upon performing the initial magnetic survey at Site A, two areas with strong anomalous readings, referred to as Sites A-1 and A-2, were discovered (Figures 1-3 and 2-1). Site A-1 was excavated first. The anomalous reading was determined to be a geophone sensor for part of the telemetry system in the area (Figure 2-2) at an approximate depth of $4 \mathrm{ft}$. After the excavation, the hole was backfilled using the excavated spoils.

Site A-2 is located approximately $20 \mathrm{ft}$ northeast of Site A-1 and consisted of a strong anomalous reading and a visual depression approximately $3 \mathrm{ft}$ in diameter. These attributes suggested that this could be the location of the projectile. This area was excavated to approximately $4.5 \mathrm{ft}$ using a backhoe at which time the nose of a projectile was uncovered. The remaining portion of the projectile was uncovered manually using hand excavation techniques, and radiological screening of the projectile and the excavated soil was performed. No readings above background were 


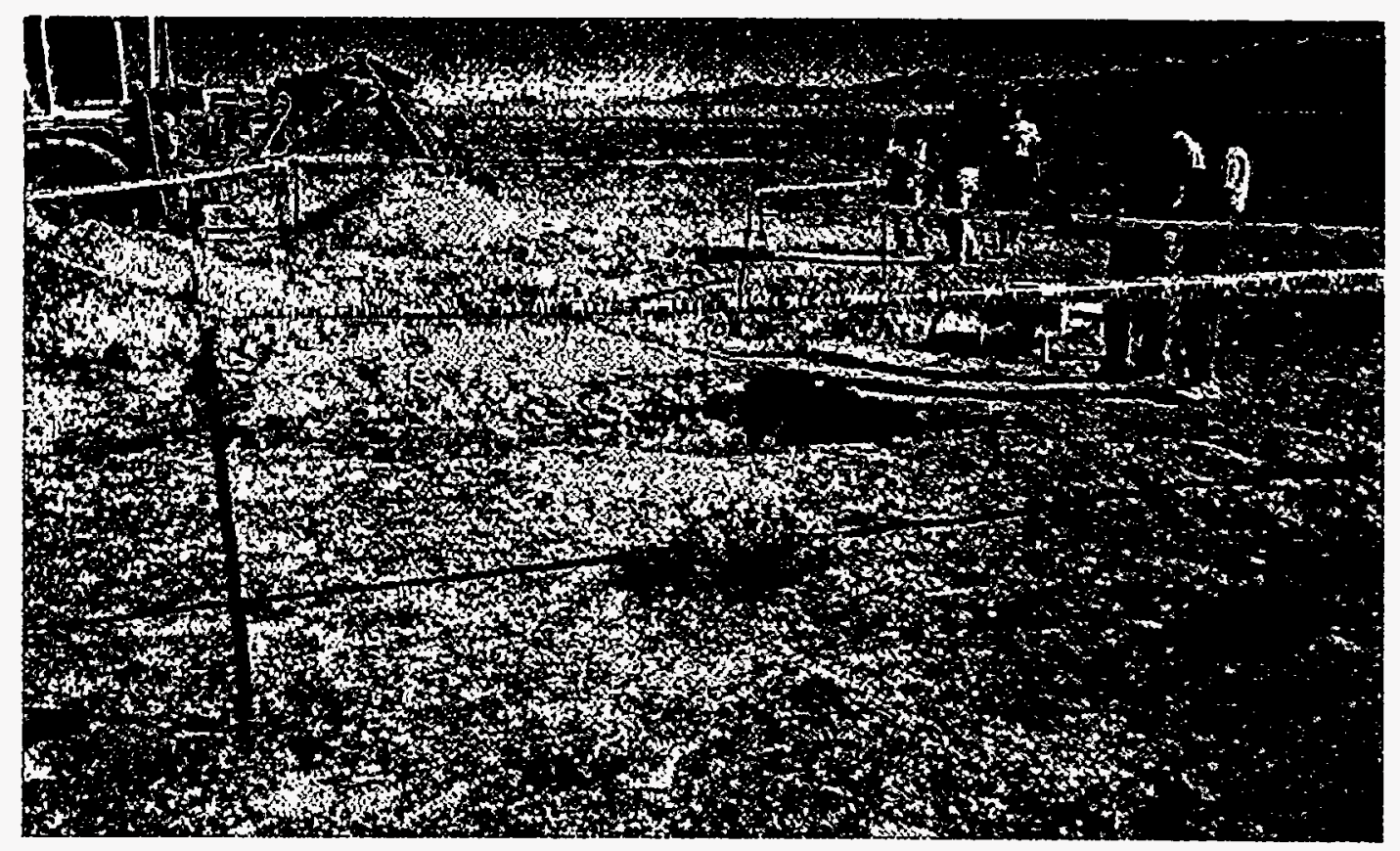

\section{Figure 2-1}

Buried DU Artillery Round No. 1, Sites A-1 and A-2, Site A-1 is in the Foreground (photo taken facing north/northeast)

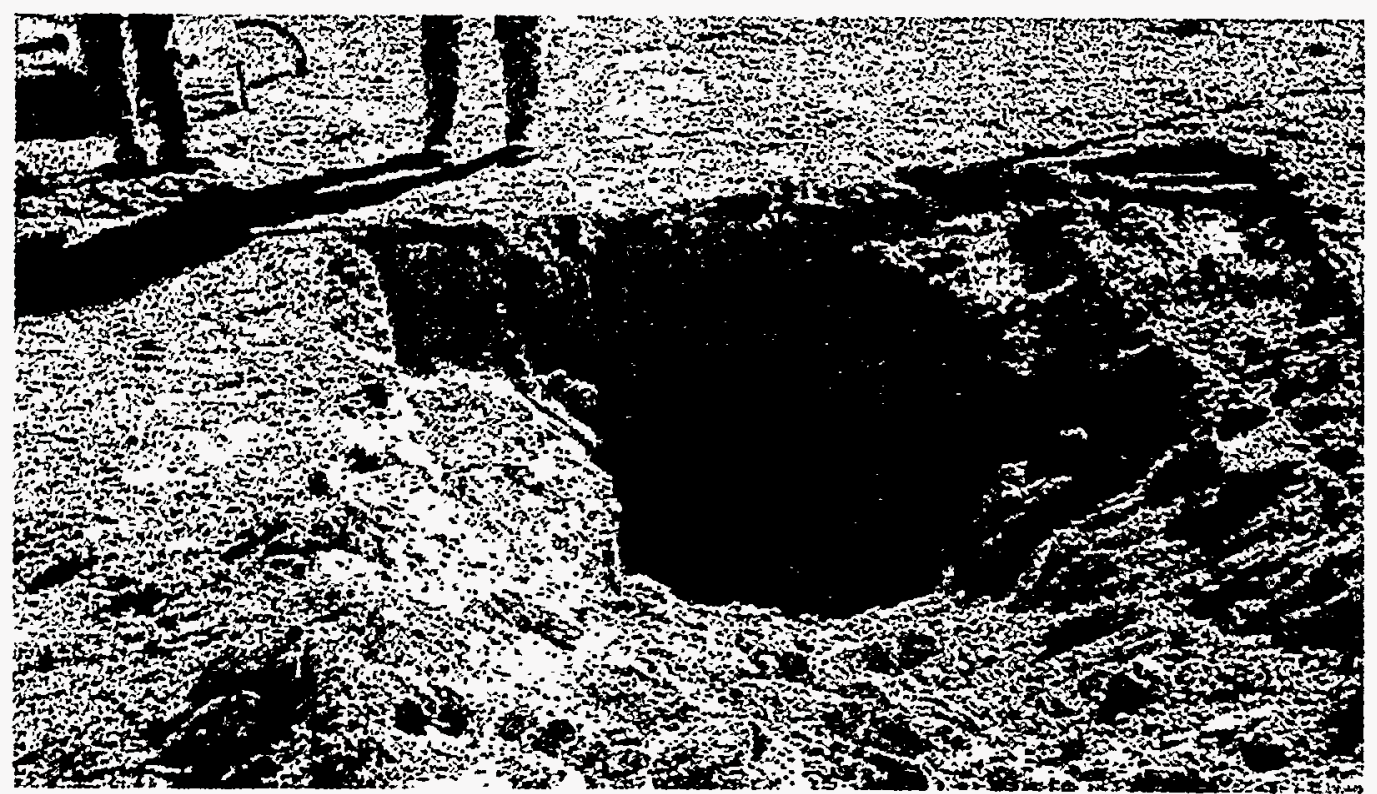

Figure 2-2

Buried DU Artillery Round No. 1, Site A-1, Geophone sensor is on right side of excavation (photo taken facing south) 
recorded. There were no identifying markings on the projectile (i.e., a serial number, INERT stamp); however, it fit the description of the W-79 projectile as follows:

- It was an 8-inch (in.) diameter projectile and was 34 in. (approximately $3 \mathrm{ft}$ ) long.

- The projectile was located in the suspected area.

- The color of one of the sections of the projectile was green which indicates a "live" round (one containing $\mathrm{HE}$ ).

- It appeared to have a parachute deployment system.

Radiological readings were not present; however, the projectile casing was intact (Figure 2-3). The projectile was treated as if it were the Buried DU Artillery Round No. 1 and was set up for destruction. Approximately 40 pounds (lbs) of Composition C-4 (high explosives) were placed on the projectile casing by USAF EOD personnel. The excavation was backfilled using the excavated spoils and the explosives were detonated (Figure 2-4). Upon reentry, a surface radiological screening survey of the area was performed using an Electra ${ }^{\circledR}$ alpha/beta meter. No elevated levels of radiation (readings greater than background) were detected through the screening survey. The detonation area was re-excavated to verify that the projectile and all components had been destroyed beyond recognition. Radiological screening was performed during re-excavation and, once again, no elevated levels of radiation were detected. Complete destruction of the projectile had occurred. Because of the absence of radiological contamination after the detonation, it was concluded that this was not the W-79 mockup which was the objective of the search. The detonated 8-in. projectile was one of the many hundreds of concrete-filled "warmer" rounds which were shot by weapons testing personnel just prior to W-79 tests. The purpose of the warmer rounds was to rehearse tracking and telemetry operations used during the actual test (Smith, 1996). The excavation/detonation pit was backfilled with the re-excavation spoils; thus, field activities proceeded to Site B.

\subsubsection{Site $B$}

Site B is approximately $140 \mathrm{ft}$ northwest of Site A-2. It consisted of a disturbed area approximately $20 \mathrm{ft}$ in diameter. After further inspection of Site B and the surrounding area, several depressions similar to the one excavated at Site A-2 were noticed. Due to what was found in Site A-2 and the fact that the test area is littered with hundreds of (inert, concrete-filled) projectiles fired as warmer rounds for the actual test rounds (Smith, 1996), the decision was 
Revision: 0

Date: $02 / 25 / 97$

Page 10 of 19

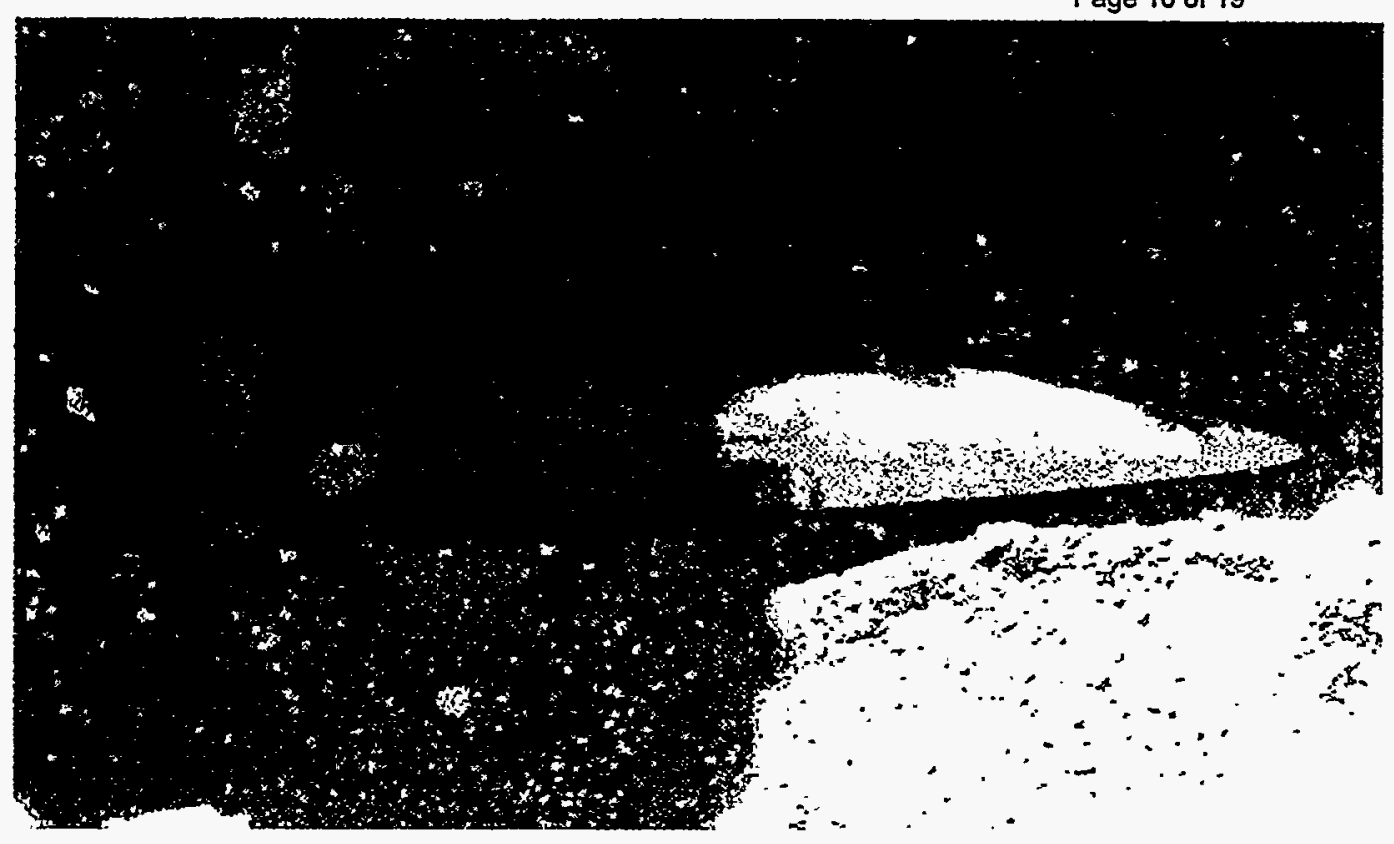

Figure 2-3

Buried DU Artillery Round No. 1, Site A-2, Excavated projectile within excavation prior to detonation (photo taken looking down into excavation)

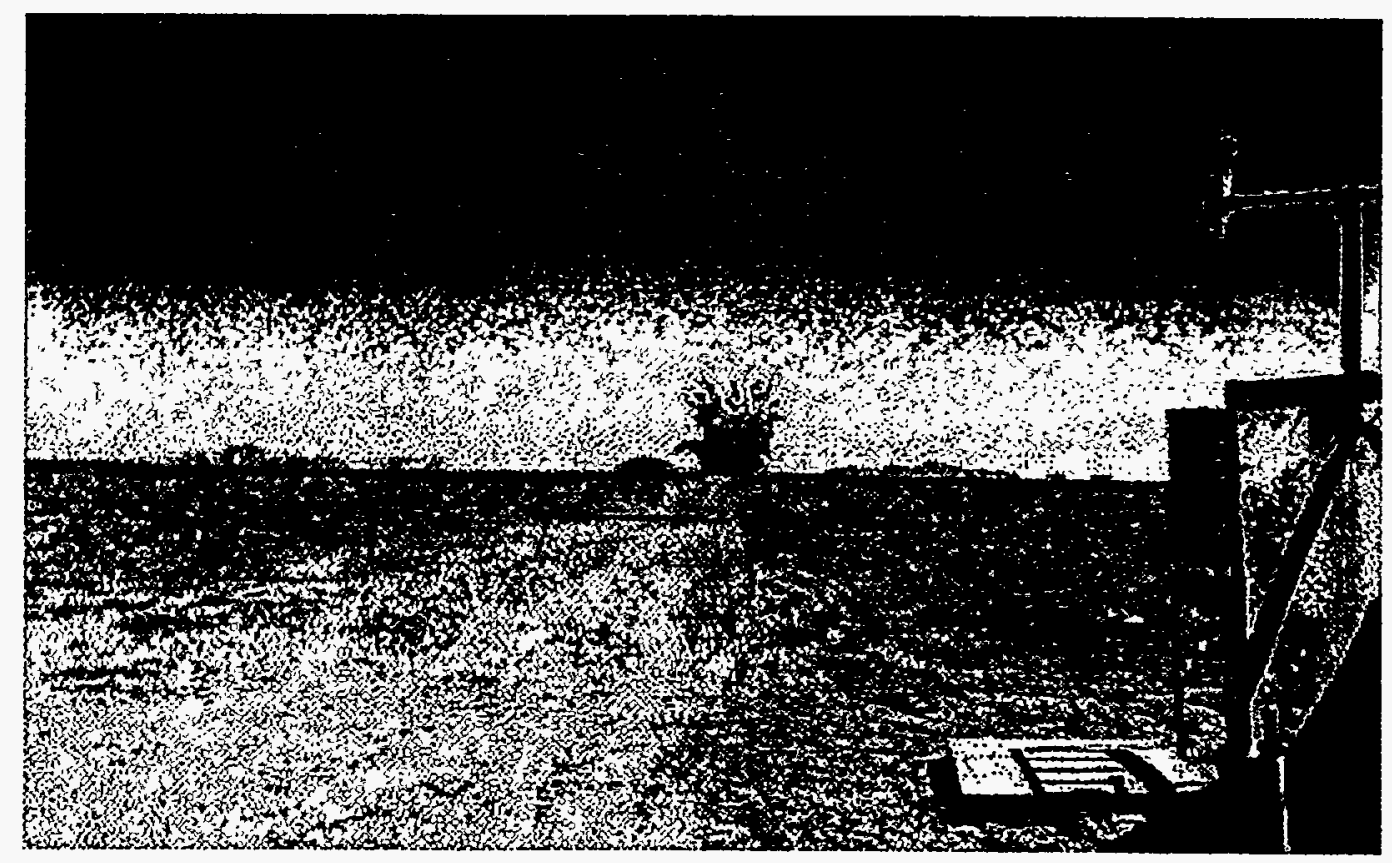

Figure 2-4

Buried DU Artillery Round No. 1, Detonation of projectile located in Site A-2 (photo taken facing south) 
made to excavate the area showing the strongest magnetic reading within Site $B$, which was not visually similar to Site A-2 (i.e., $3 \mathrm{ft}$ diameter circular depression). Site B was excavated to a total depth of $7 \mathrm{ft}$ (Figure 2-5). Each 1-ft lift of soil excavated was screened for magnetic anomalies and radiological readings; the soil within the excavation appeared to be native soil. Radiological screening results were all at or below background levels. All the magnetic anomalies were attributed to the magnetic properties of the native materials (i.e., volcanic rocks) (IT, 1996a). Based on these facts, excavation activities were stopped at $7 \mathrm{ft}$, and the hole was backfilled using the excavated spoils; thus, field activities were moved to Site C.

\subsubsection{Site $C$}

Site $C$ is the northernmost area of concern and is located approximately $960 \mathrm{ft}$ northwest of Site A-2. It consisted of a depression approximately $10 \mathrm{ft}$ in diameter and $3 \mathrm{ft}$ deep. The initial ordnance survey found weak anomalous readings in the depression. The surface radiological screening did not indicate elevated radiological readings; the pit was excavated to a total depth of $7 \mathrm{ft}$ (Figure 2-6). Each 1-ft lift of soil excavated was screened for metallic anomalies and radiological readings. The soil within the excavation appeared to be native soil. Radiological screening readings were all at or below background levels, and no strong metallic readings were obtained (IT, 1996a). Magnetic readings at this site are also believed to be from magnetic geologic materials. Based on these facts, excavation activities were stopped at $7 \mathrm{ft}$, and the hole was backfilled using the spoils.

\subsection{Deviations from the SAFER Plan as Approved}

There was a slight deviation made from the SAFER Plan (as approved). Excavation techniques included in the SAFER Plan (DOE/NV, 1996a) were written so that 3-ft layers of soil would be removed per lift. Prior to field work, it was decided that, for initial excavation activities, soil would be excavated in $1-\mathrm{ft}$ lifts to facilitate better accuracy in metallic and radiological readings.

\subsection{SAFER Plan Schedule as Completed}

SAFER Plan activities were completed as follows:

09/09/96 Field crew were mobilized to the field. Prefield trainings were conducted.

09/11/96 Field activities were postponed pending State of Nevada Division of Environmental Protection (NDEP) approval of the SAFER Plan (DOE/NV, 1996a). 
Closure Report CAU No. 430

Section: 2.0

Revision: 0

Date: $02 / 25 / 97$

Page 12 of 19

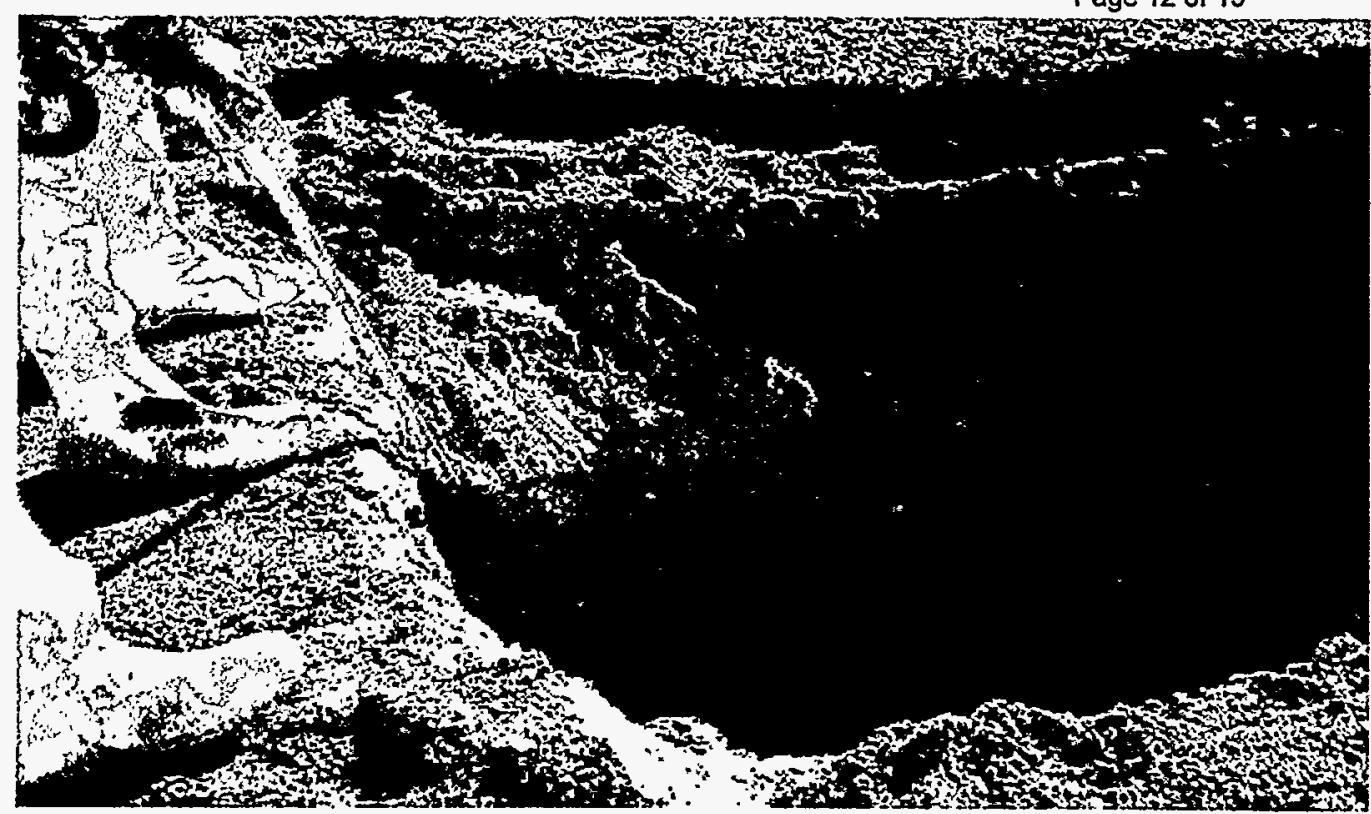

Figure 2-5

Buried DU Artillery Round No. 1, Site B, Surveying edge of excavation with a Tesoro Lobo metal detector (photo taken looking into excavation)

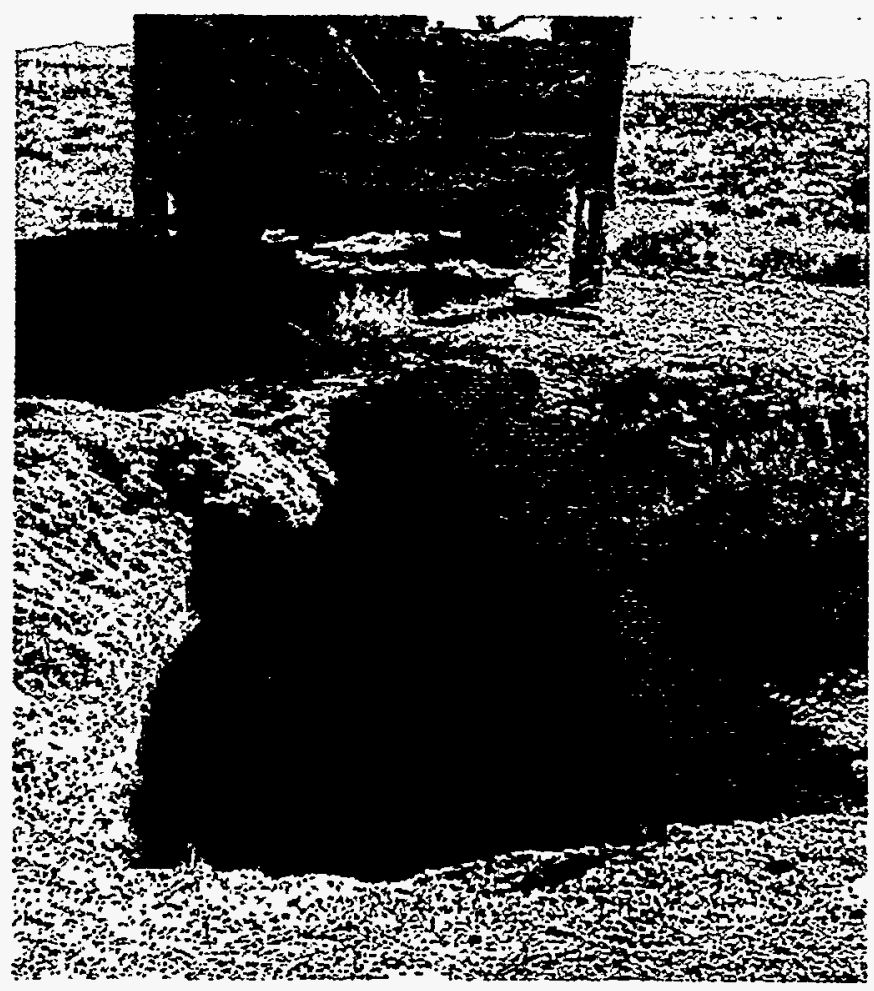

Figure 2-6

Buried DU Artillery Round No. 1, Site C (photo taken facing west/southwest) 
10/07/96 NDEP approval of the SAFER Plan (DOE/NV, 1996a) was received.

10/07/96 Field crew was remobilized to the field.

10/08/96 Excavation activities began. Site A-1 was excavated and backfilled; Site A-2 was excavated. Projectile was unearthed within Site A-2.

10/09/96 Explosive destruction of the projectile was completed.

10/10/96 Projectile was re-excavated. Destruction of the projectile was complete. No radiological contamination was detected. Excavation of Sites $\mathrm{B}$ and $\mathrm{C}$ completed, and all excavations were backfilled. SAFER Plan (DOE/NV, 1996a) field activities complete.

10/11/96 Field crew was demobilized to Las Vegas.

10/22/96 Global Positioning Survey (GPS) was performed and completed on Sites A-2, B, and $C$ at Buried DU Artillery Round No. 1.

\subsection{Site Plan/Survey Plat}

On October 22, 1996, a global positioning survey was performed on Sites A-2, B, and C to obtain geographic readings for the sites. A GPS was not performed at Site A-1 because it was part of the test area telemetry system and not of concern for this investigation. Figure 1-3 depicts the global positioning surveyed locations and the IT monuments. The IT monuments are photo documentation locations set up during a site visit in 1993 (IT, 1994). Based on the global positioning surveyed points, other items in the figure have been sketched in. 


\subsection{Waste Disposition}

During the SAFER Plan (DOE/NV, 1996a) activities, waste minimization practices were followed. Based on the negative radiological screening results, all personnel protective equipment and investigation-derived waste generated during the excavation activities were disposed of as sanitary trash. There was a small amount (approximately 1 cubic foot) of hydrocarbon-contaminated waste (soil, plastic sheeting, and vermiculite) generated as the result of a transmission fluid leak from the backhoe being used on site. The spill occurred up range by the staging area and was quickly contained with plastic sheeting; the liquid was absorbed with vermiculite. The plastic sheeting, oil soaked vermiculite, and some impacted soil were placed in a drum liner, tied shut with a waste label, and placed in a 55-gallon drum. The drum was properly labeled, locked, removed from the site, and is currently being staged in the Area 3 Compound awaiting proper disposal. 


\subsection{Field Investigation Results}

\subsection{Field Activity Results}

Sites A, B, and C were excavated during field activities at the Buried DU Artillery Round No. 1 site. The metallic anomalous readings at Sites $\mathrm{B}$ and $\mathrm{C}$ are believed to have been caused by the magnetic characteristics of the soil and rocks in the area. Site A was the only site which contained subsurface metallic items. The metallic anomaly at Site A-1 was caused by a metallic geophone sensor. Site A-2 contained an inert artillery projectile.

An attempt was made to positively identify the projectile within Site A-2 as the Buried DU Artillery Round No. 1 prior to its destruction; however, the exterior of the projectile was corroded with rust which made locating a serial number or any other identifying marking impossible (Figure 2-3). A portion of the projectile was green in color, which suggested that it contained HE and was not just an inert round. There was also what appeared to be a parachute assembly attached to the projectile. It was later determined that the assembly at the bottom end of the projectile was not a parachute assembly, but a protective skirt. There were no radiological screening results above background (IT, 1996a). Elevated readings would have been an indication that the projectile was the DU Round; however, the casing was intact which may have inhibited a radiological leak. Based on these characteristics and the fact that positive identity of the projectile could not be made, it was treated as if it were the Buried DU Round No. 1 . The projectile was destroyed using explosives. Radiological screening results of the detonation area were all at or below background radiological levels (IT, 1996a).

Based on the fact that the radiological screening results were at or below background and that the detonation was not much larger than what was to be expected for the $40 \mathrm{lbs}$ of explosives used to destroy the projectile, it was determined that the projectile destroyed was not the Buried DU Artillery Round No. 1, but was in fact one of the many inert projectiles fired prior to the actual test round (Smith, 1996). After each of the sites was excavated and field screening indicated either no additional metallic debris or, in the case of Site A-2, no radiological contamination, the excavations were then backfilled. 


\subsubsection{Quality Assurance Results}

Closure activities were performed in accordance with an approved Site-Specific Health and Safety Plan. Activities. were documented by following established field activity documentation and radiation screening protocols and procedures as per the SAFER Plan (DOE/NV, 1996a), the UXO Operations and Field Sampling Instructions for the Destruction and Remediation of Buried Depleted Uranium Artillery Round No. 1, Tonopah Test Range (IT, 1996b) and the Industrial Sites Quality Assurance Project Plan, Nevada Test Site, Nevada (DOE/NV, 1996b). All field documentation is maintained in project files. 


\subsection{Conclusion}

Four sites within three areas of concern were identified within CAS No. TA-55-003-09-60

(which comprises CAU 430). All four areas were excavated, with two of the four containing only slightly magnetic geologic materials and one containing a geophone sensor. The fourth site (Site A-2) contained an 8 in. projectile which, after detonation, was determined to be inert. The W-79 projectile, which was cited in the SAFER Plan (DOE/NV, 1996a) as containing a DU pit that was possibly detonated at this CAS, was not found. It is recommended that CAU 430, which is associated with the areas that were excavated, be closed through "No Further Action," based on the results in this report. The mock DU W-79 projectile (which was associated with the failed test in 1987) should be designated as a new CAS within a new CAU (CAU 461). Further research is needed on the location of this CAS; once located, the 1987 W-79 test projectile and other similar sites within CAU 461 will be closed in the same manner. 


\subsection{References}

DOE/AL, see U.S. Department of Energy, Albuquerque Operations Office.

DOE/NV, see U.S. Department of Energy, Nevada Operations Office.

IT, see IT Corporation.

IT Corporation. 1994. Initial Surface Geophysical Survey Report for the Tonopah Test Range Environmental Restoration Sites. DOE/NV/10972--93. Las Vegas, NV.

IT Corporation. 1996a. Field Activity Daily Logs for DU Round No. 1 Field Activities. September 10 and 11, October 8 through 22. Tonopah Test Range, NV.

IT Corporation. 1996b. UXO Operations and Field Sampling Instructions for the Destruction and Remediation of Buried Depleted Uranium Artillery Round No. 1, Tonopah Test Range. Las Vegas, NV.

Quas, J. REECo/TTR, Retired. 1996. Communication with E. Seuter, IT Corporation.

Smith, H. D. Sandia National Laboratories. 1993. Telecon between H. Duane Smith, Sandia National Laboratories; Jim Truman, IT Corporation; John Quas, REECo/TTR; and Randy Dubiskas, IT Corporation, about Buried DU Rounds \#1 and \#2. 28 July.

Smith, H. D. Sandia National Laboratories. 1996. Communication with E. Seuter, IT Corporation. January.

SNL, see Sandia National Laboratories.

Sandia National Laboratories. 1988. 1987 Environmental Monitoring Report, Tonopah Test Range, Tonopah, Nevada. Prepared by G.C. Millard and G.L. West. Albuquerque, NM: Sandia National Laboratories.

U.S. Department of Energy, Albuquerque Operations Office. 1992. Tonopah Test Range Environmental Monitoring Plan. Albuquerque, NM.

U.S. Department of Energy, Nevada Operations Office. 1992. Tonopah Test Range Tour. April 28. Tonopah Test Range, NV. 
U.S. Department of Energy, Nevada Operations Office. 1996a. Streamlined Approach for Environmental Restoration Plan, CAU No. 430: Buried Depleted Uranium Artillery Round No. 1, Tonopah Test Range. DOE/NV--446. Las Vegas, NV.

U.S. Department of Energy, Nevada Operations Office. 1996b. Industrial Sites Quality Assurance Project Plan, Nevada Test Site, Nevada, Revision No. 1. DOE/NV--372. Las Vegas, NV. 


\section{Copies}

Janet Appenzeller-Wing

1 (Uncontrolled)

DOE/Nevada Operations Office

P.O. Box 98618

Las Vegas, NV 89193-8518

Kevin Cabble

1 (Controlled)

DOE/Nevada Operations Office

P.O. Box 98618

Las Vegas, NV 89193-8518

Sabrina Bonnell

1 (Controlled)

Environmental Restoration Division Records Center

DOE/Nevada Operations Office

P.O. Box 98618

Las Vegas, NV 89193-8518

Mr. Paul Liebendorfer

2 (Controlled)

State of Nevada

Bureau of Federal Facilities

Division of Environmental Protection

$333 \mathrm{~W}$. Nye Lane

Carson City, NV 89710

Chuck Bulik

1 (Controlled)

State of Nevada

Division of Environmental Protection

Las Vegas, NV

Ken Beach

IT Corporation

1 (Uncontrolled)

4330 S. Valley View, Ste. 114

Las Vegas, NV 89103

Randy Dubiskas

1 (Uncontrolled)

IT Corporation

4330 S. Valley View, Ste. 114

Las Vegas, NV 89103 
Distribution List

\section{Copies}

Angelica Russell

1 (Controlled)

IT Corporation

4330 S. Valley View, Ste. 114

Las Vegas, NV 89103

Central Files

1 (Uncontrolled)

IT Corporation

4330 S. Valley View, Ste. 114

Las Vegas, NV 89103 